\title{
When the Roots Go Round and Round
}

\author{
Gary W. Watson and Sandra Clark
}

\section{Investigations of girdling root formation in landscape trees shed light on life in the tree pit.}

Several decades ago, American elms dominated our urban landscapes. When large numbers of them succumbed to Dutch elm disease, they were replaced by new plantings that were somewhat less homogenous, but still limited in most cases to a handful of species. Maples, especially Norway maples, were commonly included in these replacement plantings in the Midwest and elsewhere. Norway maples were considered well suited to urban landscapes because of their attractive form and foliage. Moreover, they are easy to propagate and transplant, as well as tolerant of a wide variety of soil conditions.

A few decades later, as some of these Norway maples approached maturity, many started to decline unexplainably, raising new fears of devastating tree losses. Typical canopy symptoms included reduced growth, abnormal color, early fall coloration, and dieback. There was no evidence of diseases, pest infestation, or any other aboveground problem. However, investigations below the ground

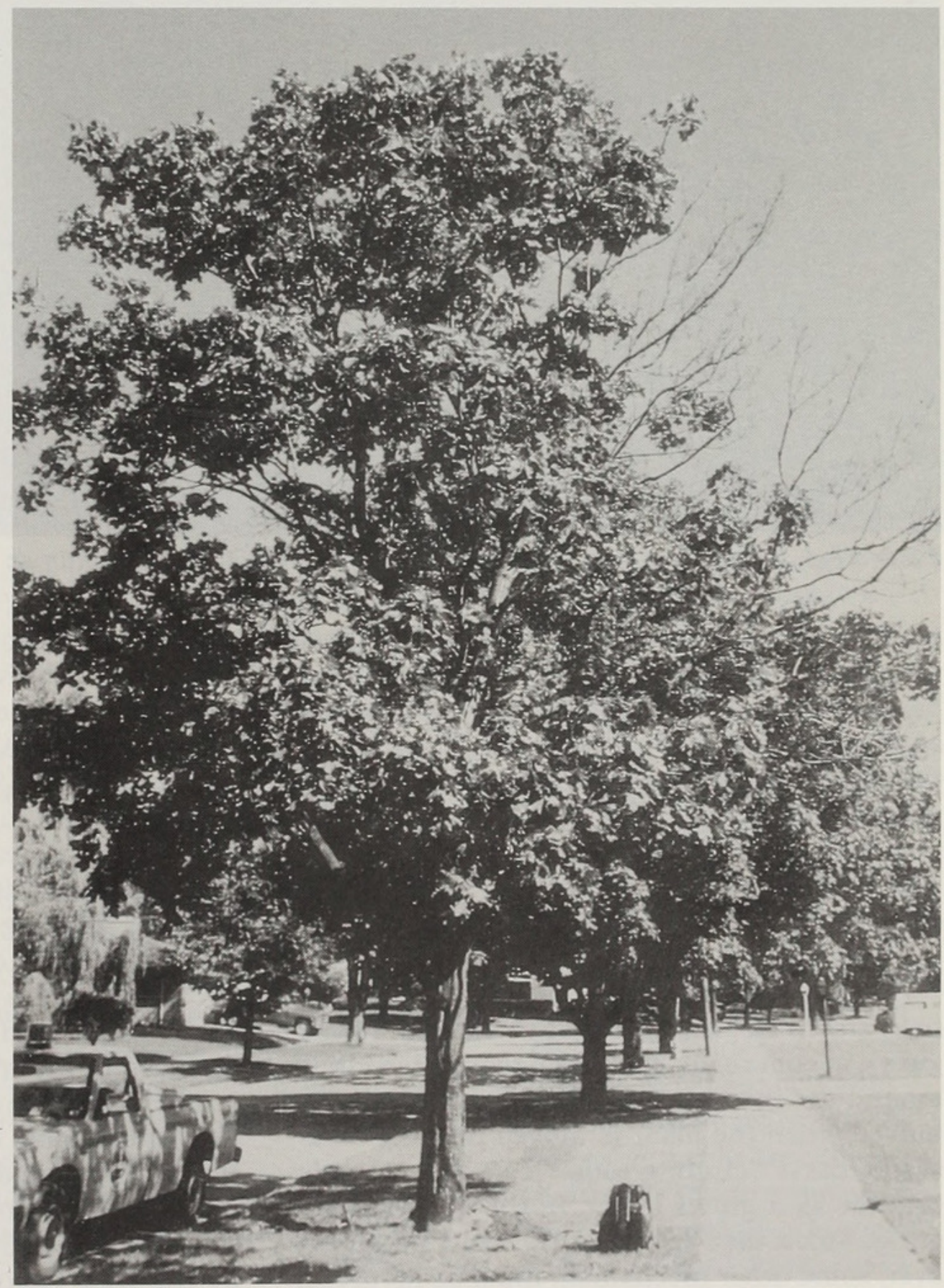

The canopy of a Norway maple in Mt. Pleasant, Illinois, shows symptoms of girdling roots: reduced growth, abnormal color, and dieback. 


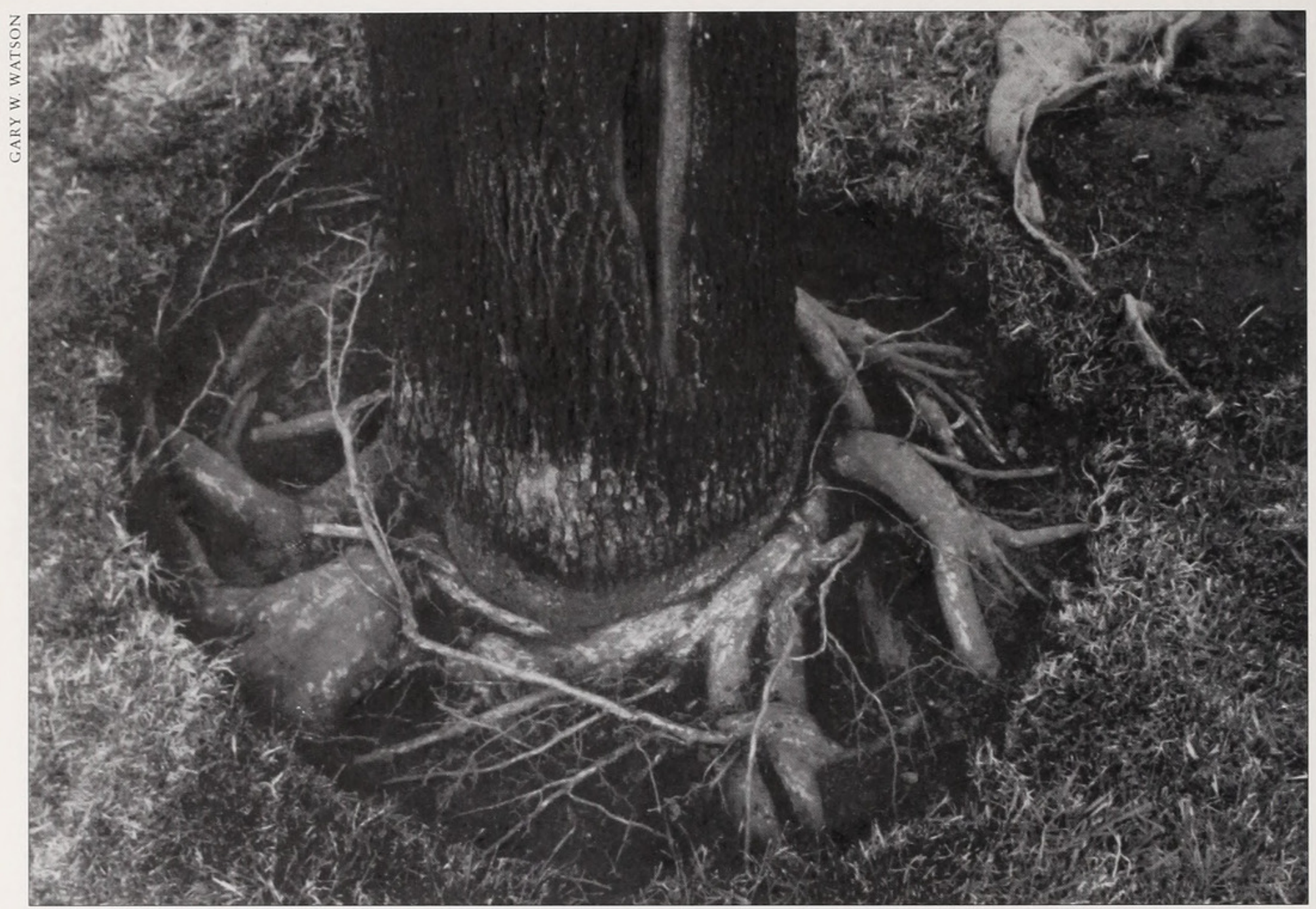

Excavation of the root crown reveals a typical girdling root formation in an older Norway maple.

began to reveal that a high percentage of these trees had girdling roots. ${ }^{1}$ A girdling root has been defined as "a root that grows around another root or stem, thus tending to strangle the plant."2 Where the girdling root contacts the trunk, radial growth of both the trunk and root is distorted and reduced. Normal movement of water and nutrients from the roots to the canopy is greatly decreased, leading to stress and then to decline.

How and why these girdling roots form on field-grown trees is unknown. When plants are grown in containers, of course, roots often circle around the interior of the pot. If not cut or removed when the plant is moved into the landscape, these "circling roots" can also strangle the tree as it grows larger. In the case of fieldgrown stock that has never been in a pot, however, some other mechanism must be involved.

Girdling roots on Norway maples are recognized all over the country as a major problem, and the Chicago area is no exception. As an example, in the suburb of Mt. Prospect, where they represent seventeen percent of all street trees, some of the Norway maples were reaching mature size by 1987, and some were declining because of girdling roots. At that time, we initiated a study to learn what caused girdling roots and how they might be corrected or prevented. Because girdling roots had been reported on sugar maple (Acer saccharum) and red maple (A. rubrum) as well as Norway maple (A. platanoides), all three of these species were included in the study. ${ }^{3}$

The first phase of the work, involving excavation of the roots of large Norway maples (over twelve inches in diameter), showed that girdling roots can wrap around the entire trunk circumference before crown symptoms develop. In fact, by the time canopy decline becomes evident, the girdling is often at an advanced stage, with the roots so intertwined that little can be done 


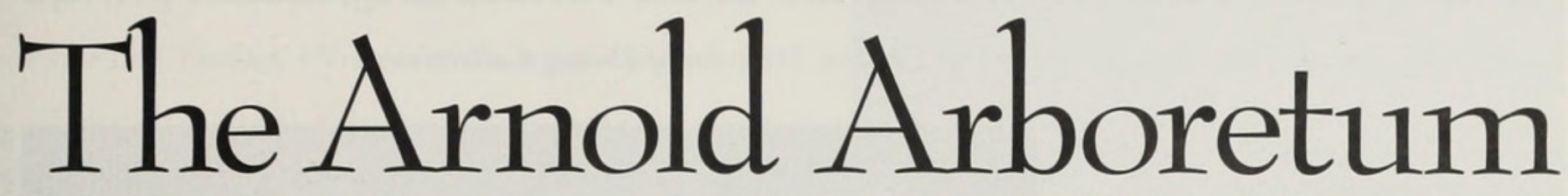

$\begin{array}{llllllllllllllll}S & P & R & \text { I } & N & G & \bullet & N & \text { E } & W & S & \bullet & 1 & 9 & 9 & 6\end{array}$

\section{A New Board and Council}

\section{Robert E. Cook, Director}

Over the past winter some friends of ours gathered together on several occasions to discuss the creation of a new organization of volunteers to support the work of the institution. These meetings grew out of a recognition that most museums and cultural organizations like the Arboretum enjoy the active involvement of a board of trustees. Such groups have proven immensely helpful in promoting knowledge of the institution's programs and in raising funds for annual operations and capital improvements.

No such group exists for the Arboretum.

By tradition, the Director has reported to the Dean of the Faculty of Arts and Science at Harvard. Since 1989 my boss has been Sally Zeckhauser, Vice President for Administration, who in turn reports to the President. Also by tradition, the Arboretum has had a Visiting Committee appointed by Harvard's Board of Overseers to review the programs and progress of the organization and report back findings to the Overseers every three to five years. Basically, the Visiting Committee performs the vital role of communications with the administration of the University.

The new creation will begin regular meetings next fall and will

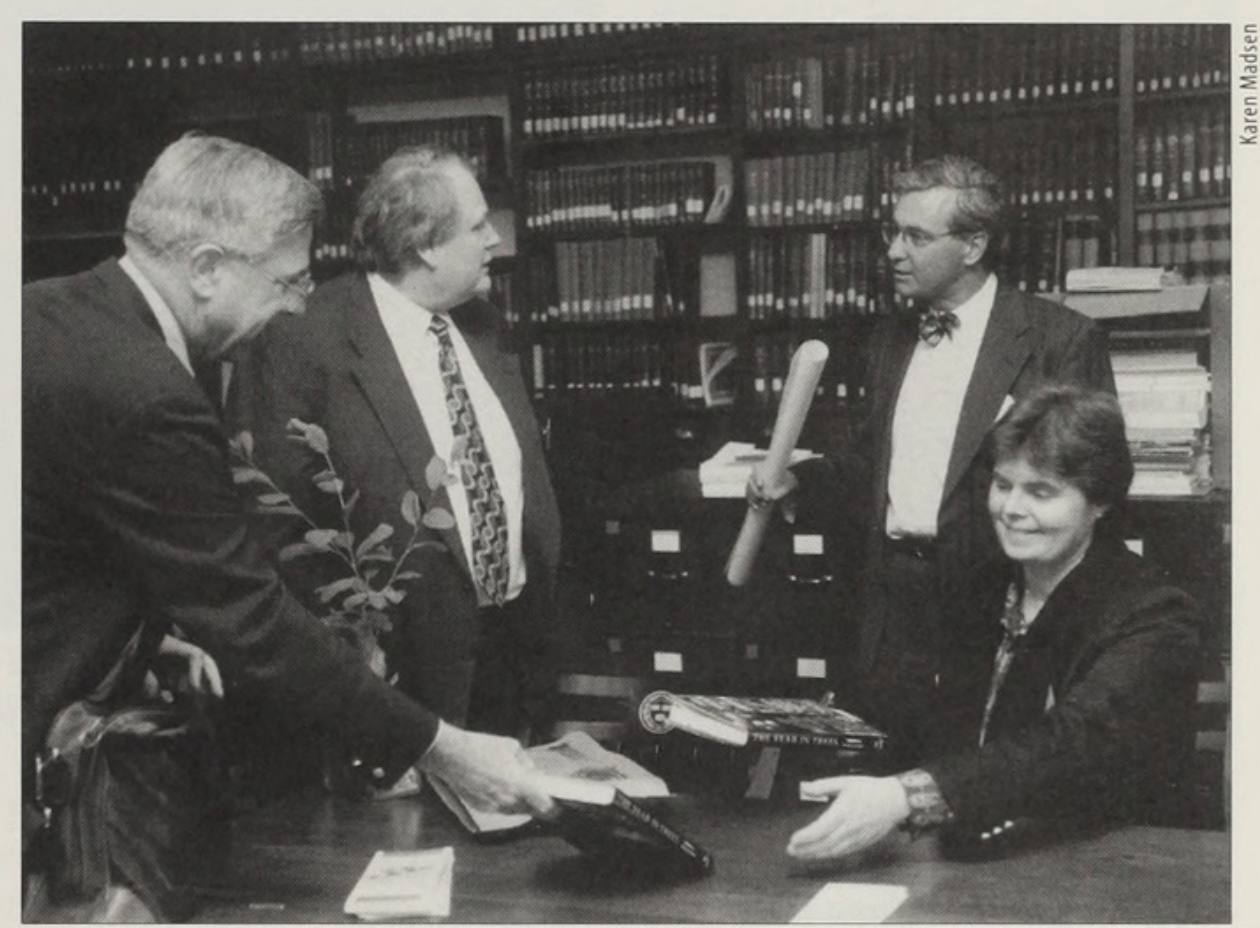

At the April meeting of the Arboretum's Visiting Committee, Putnam Fellow Kim Tripp (right) signed copies of her book, The Year in Trees, for Professor Hardy Eshbaugh of Miami University of Ohio (left) and Bob Bartlett of Bartlett Tree Company. Bob Cook stands to Kim's right. Also in the photo, on the library table, is one of the plants of Heptacodium miconioides that were given to committee members.

be called the Director's Advisory Board. A group of fifteen to twenty-five individuals will meet through the year to provide counsel to the Director, recruit new volunteers, and develop strategies for raising funds for annual support and future programs. The Advisory Board will have several standing committees (executive, campaign, nominating), as well as commitees focused on specific programs.

Our friends have also recommended the creation of a second, larger body called the Arboretum Council. This group will meet once or twice each year and will consist of three kinds of members: individuals new to the Arboretum who would like to learn more about its programs before volunteering the greater commitment required by the Board; individuals with limited time but great interest in the Arboretum; and former members of the Board and the Visiting Committee.

If you would like to become more involved in supporting the Arboretum and its programs, perhaps as a volunteer for one of these two new groups, drop me a note or an E-mail. I would enjoy talking with you about the possibilities. 


\section{"New" Plants From a New Program at the Arnold Arboretum}

\section{Kim Tripp, Putnam Fellow, and Peter Del Tredici, Director of Living Collections}

The Arnold Arboretum is home to 278 acres of woody plants, many of which have proven to be beautiful, stress tolerant, free of serious pests and diseases, unusual, and yet adaptable to modern nursery production and landscape use. In order to make plants with excellent ornamental potential more widely available to nurseries and, eventually, to the gardening public, we have instituted a new Arnold Arboretum plant introduction, promotion, and distribution program. Our goal is to get exceptional woody plants now in the collections of the Arnold Arboretum into the hands of progressive nurseries and other botanical institutions. To achieve this goal, we will be selecting woody ornamentals with good landscape potential from the collections for increased promotion and direct distribution.

Each year the Living Collections staff will select plants of particular merit and distribute small

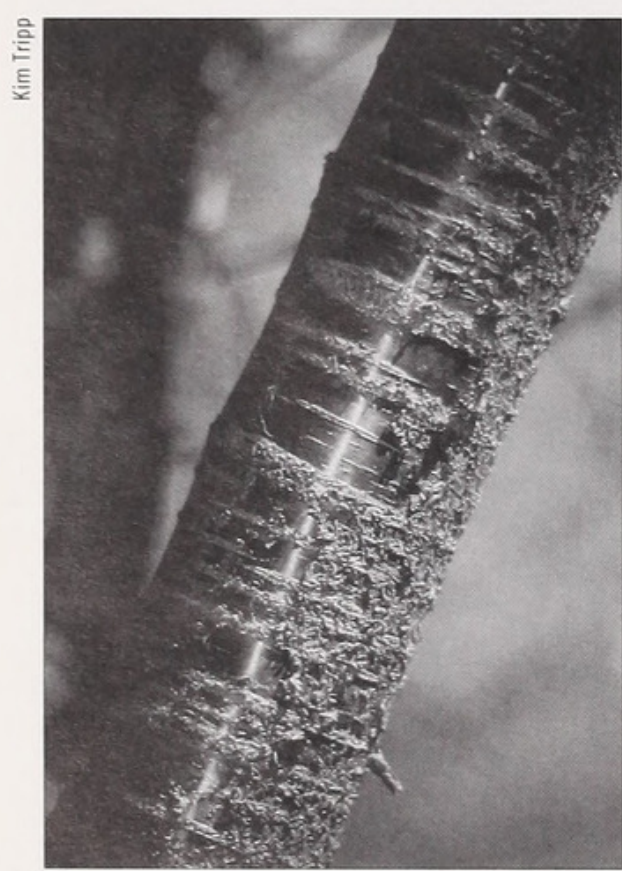

The very ornamental bark of Prunus cyclamina, cyclamen cherry.

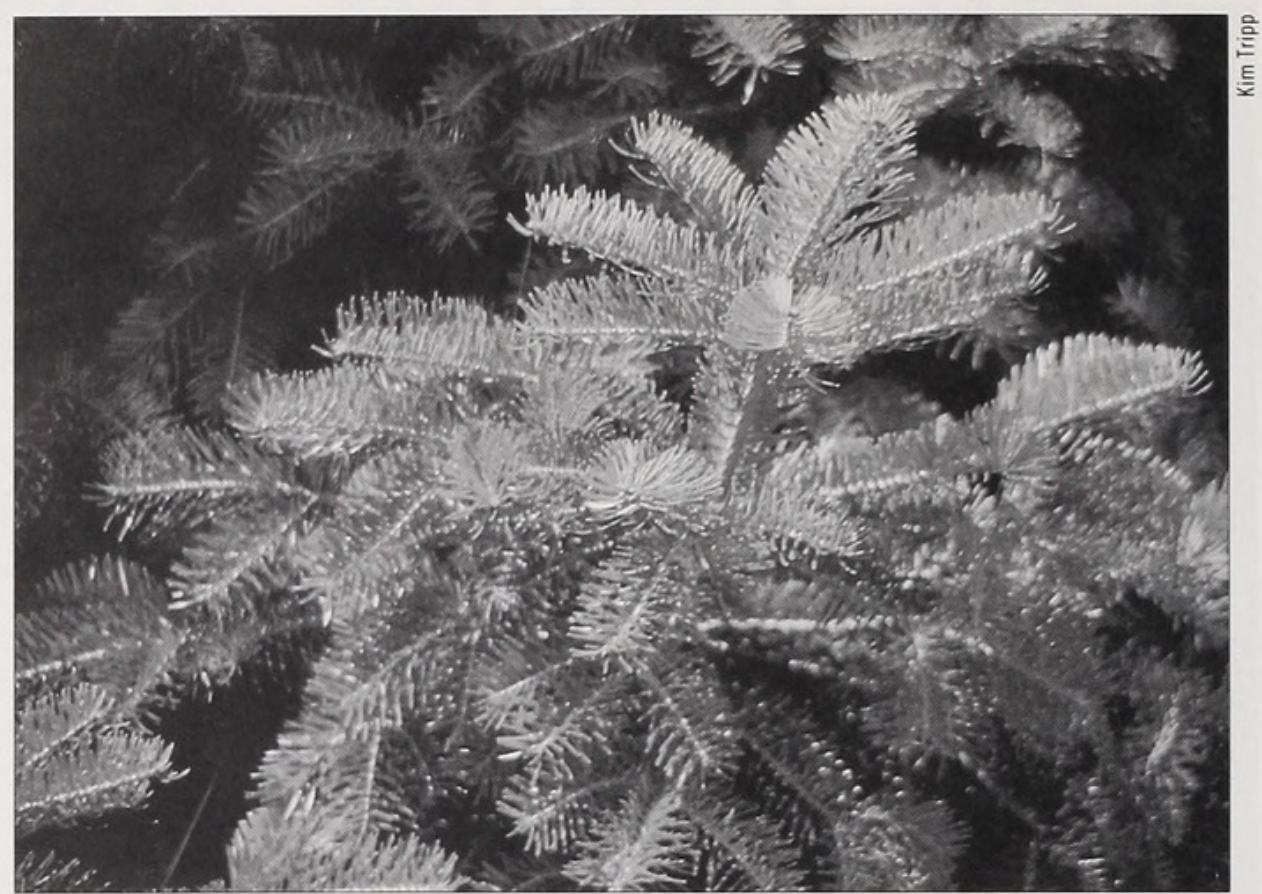

Abies borisii-regis, King Boris fir, develops a uniformly dense habit as a young tree and keeps good winter color with no bronzing or dieback.

quantities of scions and cuttings to professionals who can then propagate plants for trial and eventual sale to the gardening public. The excellent collections records at the Arboretum has enabled the staff to evaluate performance of these plants over a period of decades. Extensive records of propagation trials, in combination with ongoing propagation work at the Dana Greenhouses, also enable us to offer sound propagation recommendations.

Professional horticultural organizations and commercial nurseries are invited to subscribe to the Arnold Arboretum Plant Introduction, Promotion, and Distribution Program on an annual basis. Subscribers will be offered:

- Direct delivery of scions, cuttings, or seed of exceptional plants in the collections

- Written reports and plant profiles including: descriptions, propagation and cultural recommendations, and landscape per- formance history at the Arnold Arboretum

- An invitation to an annual Subscribers' Propagation Workshop, which will include guided opportunities to collect from much of the Living Collections.

Our 1996 selections are Abies borisii-regis, King Boris fir (USDA zone 5), Magnolia grandiflora 'Tulsa', a clone of bull bay magnolia selected by Lester Case of Winchester, Massachusetts (USDA zone 6), and Prunus cyclamina, cyclamen cherry, a highly ornamental species with unusual reliability (USDA zone 6, possibly 5). Funding generously provided from the Stanley Smith Horticultural Trust and the Willowwood Foundation has made it possible for us to initiate this new program.

If you are a nursery professional or professional horticulturist interested in learning how to participate in the program, please contact Kim Tripp by fax at 617/524-6413. 


\section{Spring Planting 1996}

Peter Del Tredici, Director of Living Collections

The one thing that can be said for certain about this spring's weather is that it has been good for the plants. Unlike the past few springs with their below-average precipitation, this one provided subtantial moisture at intervals that seemed to occur every other day. In addition, the cool temperatures in May held the plants back enough to allow the entire list of spring plantings to be dug in before leafing out. Were it not for a surprise snowstorm late in April, 1996 might qualify as a perfect spring for transplanting.

Among the highlights of the planting season was the completion of the replanting of the Chinese Path area, where we added more Corylopsis species, four specimens of Lindera obtusiloba, a young plant of Chionanthus retusus (the Chinese fringe tree), and the relocation of a twentyfoot-tall specimen of Acer triflorum. The addition of these plants, together with containerized plants to come later this spring, will conclude the renovation of the area, making it not only more beautiful, but also much more accessible to pedestrians.

It was a particular pleasure to see the new plantings on Peters Hill, which featured numerous accessions of cherries, pears, hawthorns, and crabapples, thereby insuring the beauty of that area for future generations of Arboretum visitors. Over the course of the last three years, the Peters Hill area has undergone a nearly com-

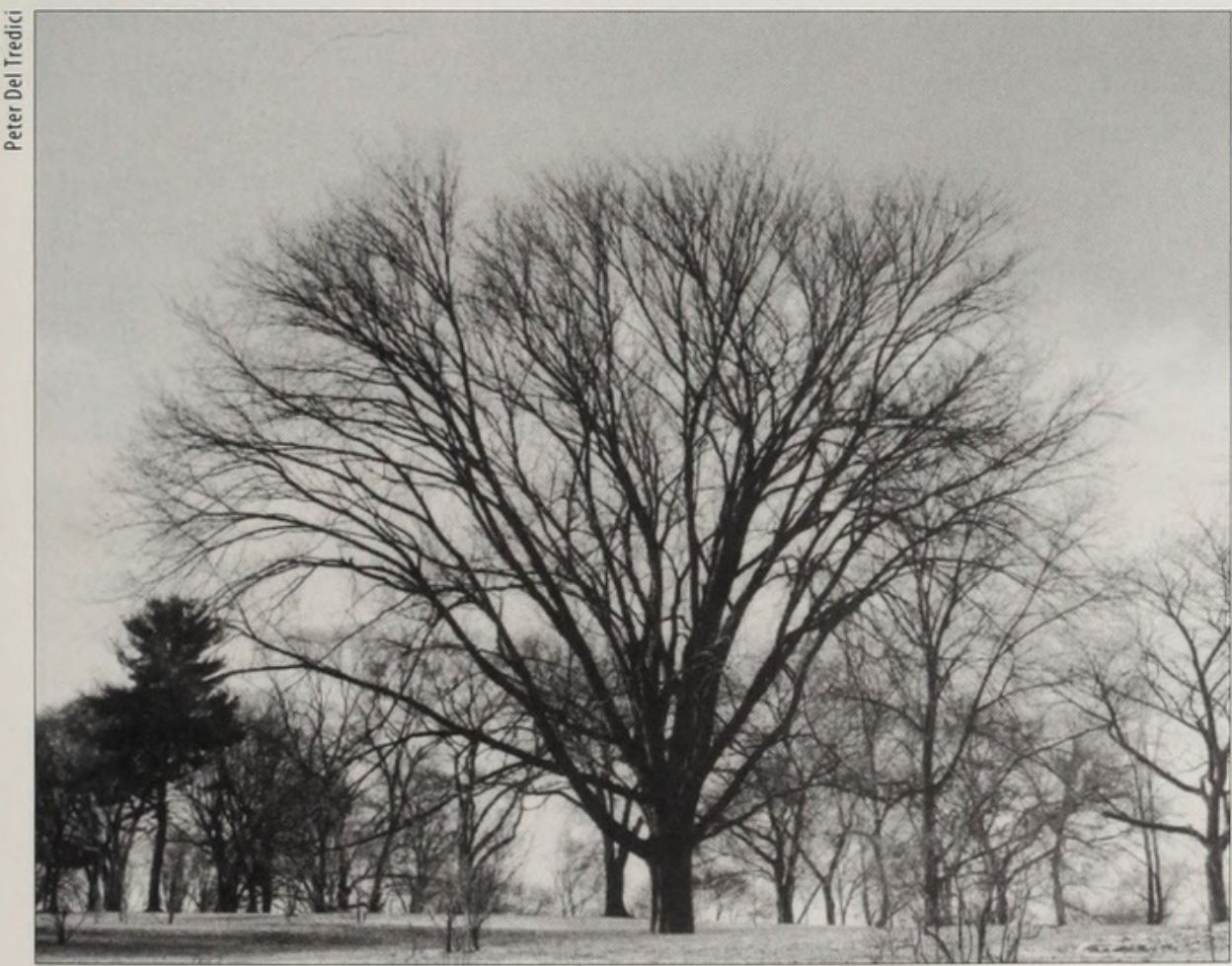

This specimen of Ulmus americana 'Princeton' has been growing on Bussey Hill since 1935. Scions of this disease-resistant cultivar were among the new spring plantings.

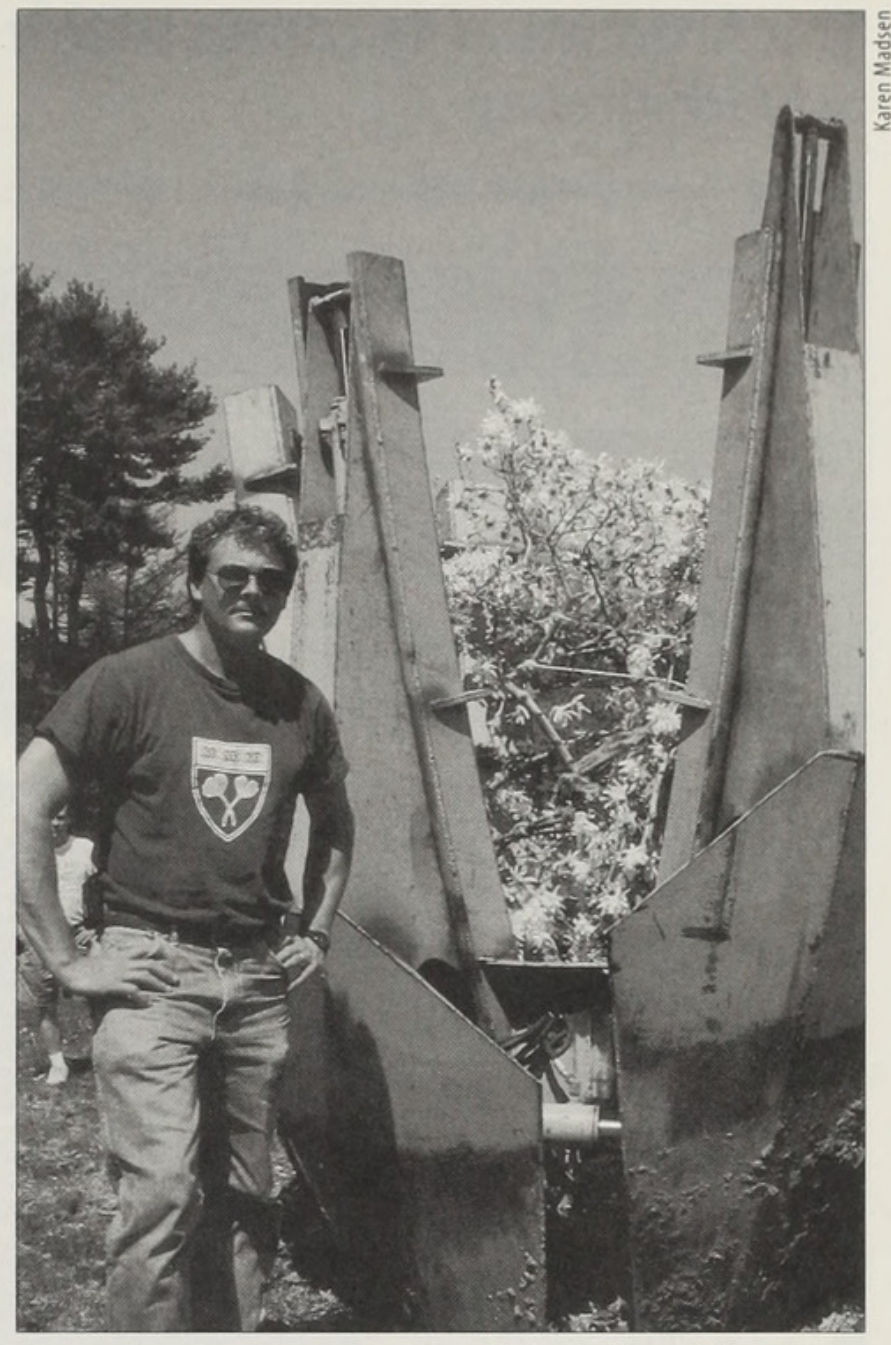

Grounds superintendent Patrick Willoughby next to Magnolia stellata, in the jaws of a tree spade that has uprooted it for replanting near the Hunnewell Building.

plete transformation that will be capped with a redesign of the summit sometime in 1997

In addition to these two areas, the rest of the Arboretum was liberally sprinkled with a variety of new plants, including maples, alders, birches, the new Cornus florida $\mathrm{x}$ kousa hybrids from Rutgers University, oaks, redbuds, ashes, and the disease-resistant cultivar of the American elm, 'Princeton'. Perhaps the most unusual specimen planted this year was a hackberry from China, Celtis vandervoetiana, which is perhaps the only one of its kind in North America. We hope this new generation of trees will in some measure compensate for the weather-related losses of the past two years. 


\title{
The Arboretum Becomes a New Stop on the Information Superhighway
}

\author{
Chris Strand, Outreach Horticulturist
}

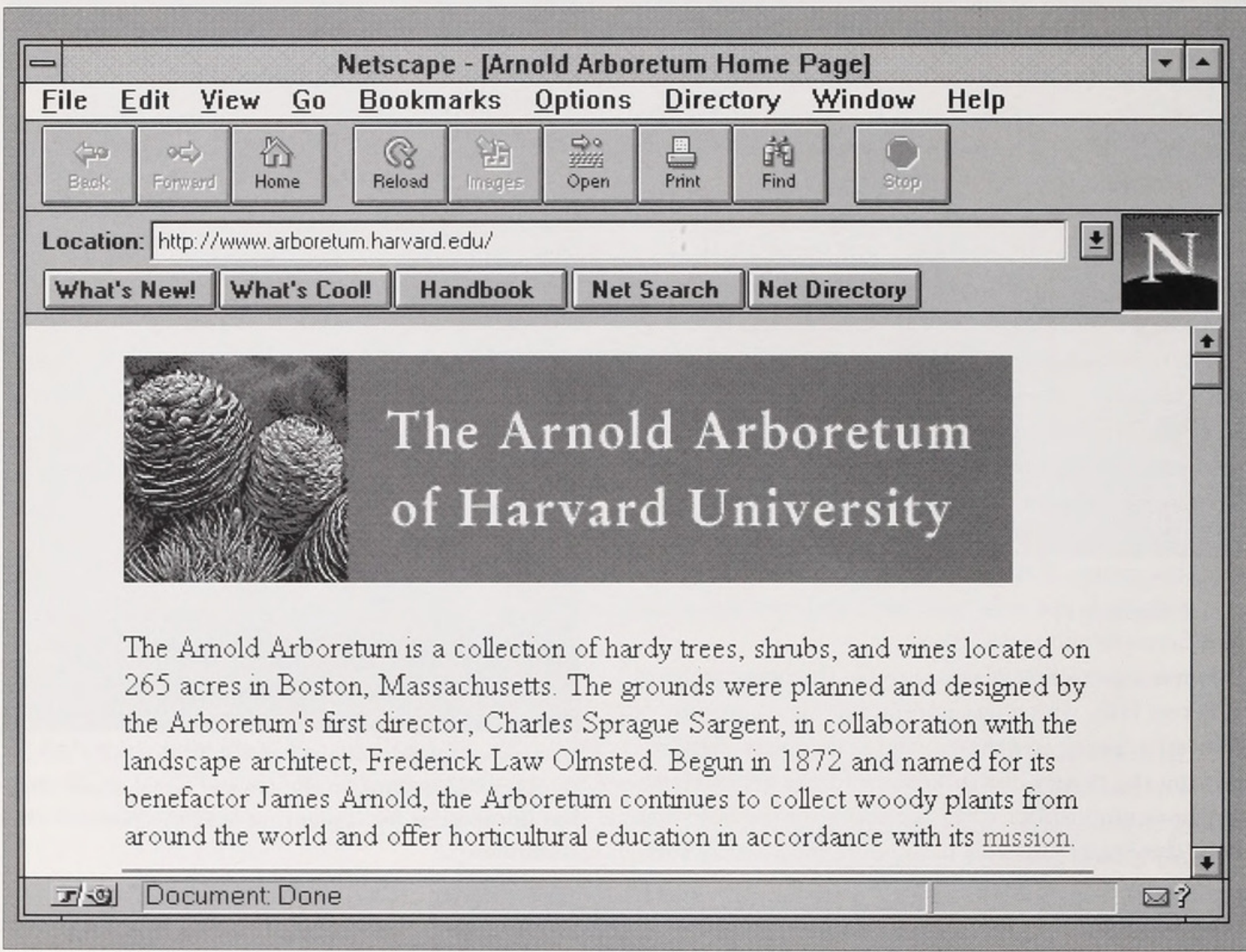

The first page of the Arboretum's World Wide Web site as seen on the computer screen.

On April 1, the Arnold Arboretum became part of the growing community of botanical gardens offering information over the World Wide Web. The web, as it is often abbreviated, is a global computer network that allows users to view images, send electronic mail, read articles, and query databases - all from a personal computer

The Arboretum's new home page is organized by five basic areas of content: living collections, library and archives, membership, public programs, and visitor information. Some of the page's highlights include a library catalog, a detailed bloom schedule for the Boston area, an inventory of our living collections, course listings for spring and summer educational programs, and articles on woody plants and landscape design.

The World Wide Web is a convenient and potentially powerful way to communicate with new audiences. As of 1995 nearly 10 million users had accessed the web for information, and it is predicted that over 15 million will access the web in 1996. Most classrooms have or are acquiring connections to the World Wide Web, and our own children's education program has begun a project called the Community Science Connection that will link sixteen schools to the Arboretum and one another through the World Wide Web.

To some of our members, this emphasis on technology may seem somewhat uncharacteristic. Although it is true that our web site was unveiled on April Fool's Day, we are serious in our commitment to find new ways to share the Arboretum with the public. After all, we are not proposing to create a virtual Arboretum-there remains no silicon substitute for walking beneath trees. 


\section{Annual Fall Plant Sale}

\section{Lisa Hastings, Development Officer}

Planning is well underway for the Arboretum's Annual Fall Plant Sale, which will take place this year on Sunday, September 15, from 9:00 am-1:00 pm at the Case Estates in Weston. One of the premier horticultural events of the fall season, the plant sale offers distinctive and unusual trees, shrubs, and perennials, many propagated from the Living Collections at the Arboretum. Our largest member event of the year, members receive a free plant dividend, discounts on all purchases, and early entrance to the sale.

A sampling of the plants to be offered this year include: Cornus florida 'Xanthocarpa', Pistacia chinensis, Abeliophyllum distichum 'Roseum', Euonymus carnosus, Hypericum buckleyi, Ilex verticillata 'Winter Gold', Neillia thibetica, Prinsepia sinensis, Clematis serratifolia, Tsuga diversifolia, and Spigelia marilandica. A complete plant sale catalog, including plants in the Collector's Choice category, will be mailed to all members in early August.

This year's plant sale will also feature the return of the Silent Auction, to take place from 9:00 to 11:15 am, and the Rare Plant Auction at 11:30 am. The auctions, proceeds of which benefit the curation and maintenance of the Arnold Arboretum's Living Collections, will feature rare and unusual plants donated by nurseries located throughout the United States. Finally, plant societies from around New England will participate in Society Row, located in the field and open from 9:00 am-1:00 pm.

If you have question about the plant sale or are interested in volunteering, please contact Chris Strand, 617/524-1718 x 125, or Kara Stepanian, x 129. Mark your calendar and plan to join us!

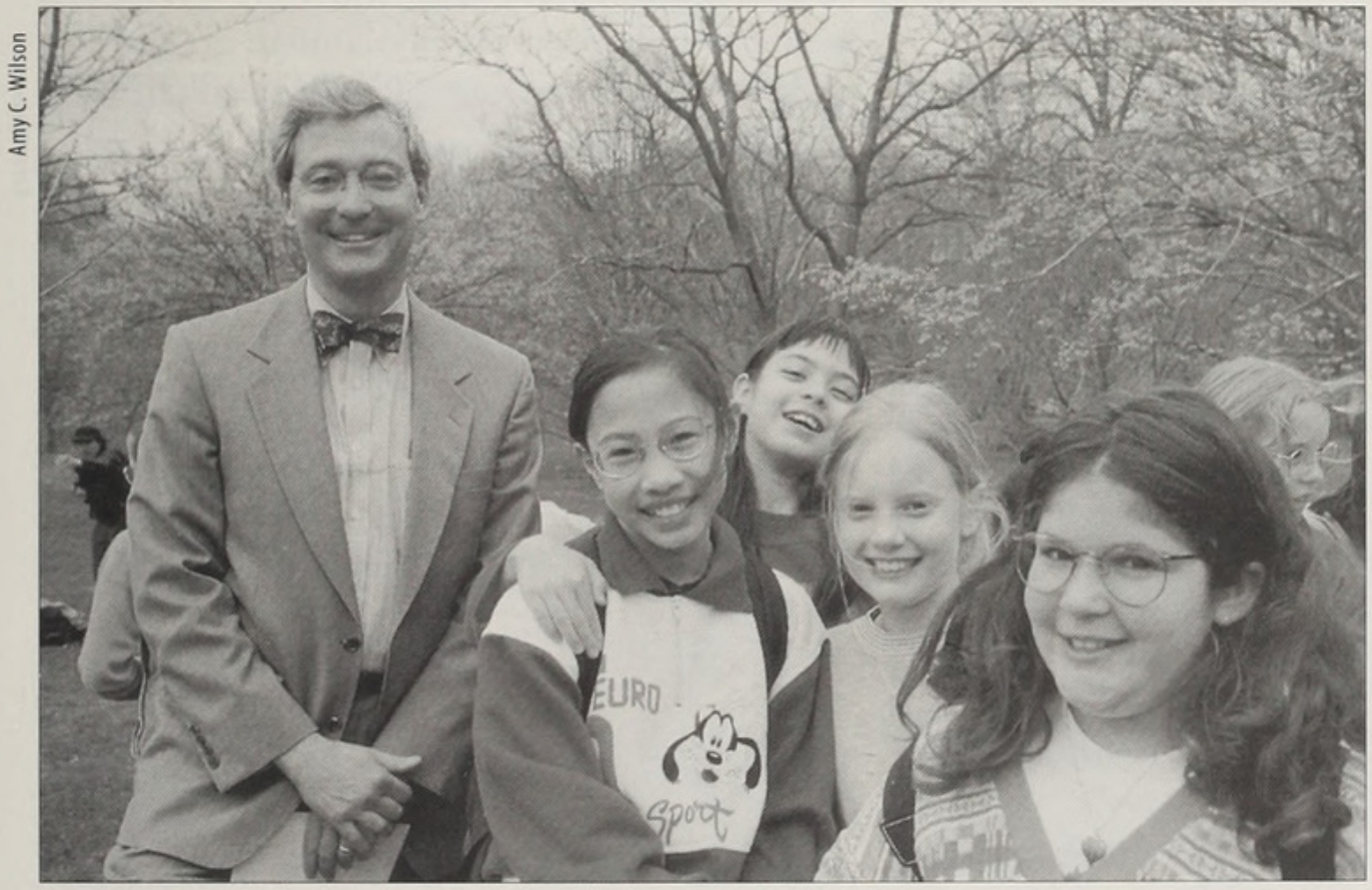

In April, a young cork tree (Phellodendron amurensis) was planted near Meadow Road in the former shade of the 121-year-old veteran that fell under the weight of twenty-two sixth-graders last fall. The five-year-old was welcomed with great ceremony, and Winsor School students presented Director Bob Cook with a $\$ 300$ check to help ensure a long and happy life for the newcomer.

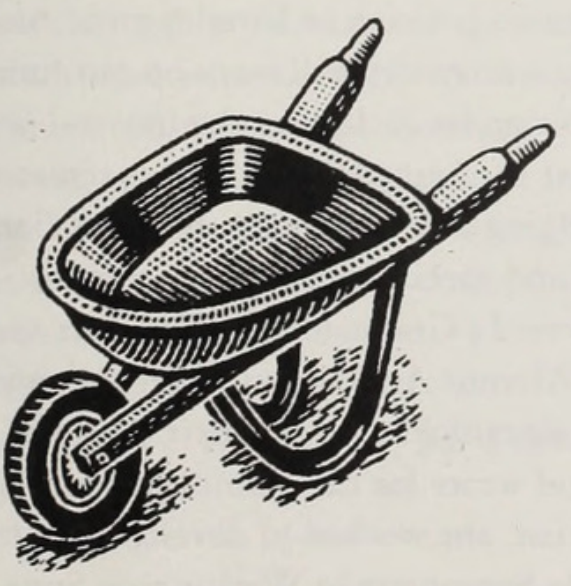

\section{Wanted! Needed! Help!}

The Arnold Arboretum is currently working on a permanent exhibit for the Hunnewell Building that will be unveiled in October. We are searching for two items that are intrinsic to our "story": a 1950s-era wheelbarrow in relatively good condition and two or three empty burlap bags - preferably with no marks on one side.

If you can donate these items, you will receive a special invitation to the opening along with our heartfelt thanks. Please contact Chris Strand at 617/524-1718 x 125. 


\section{Gone West}

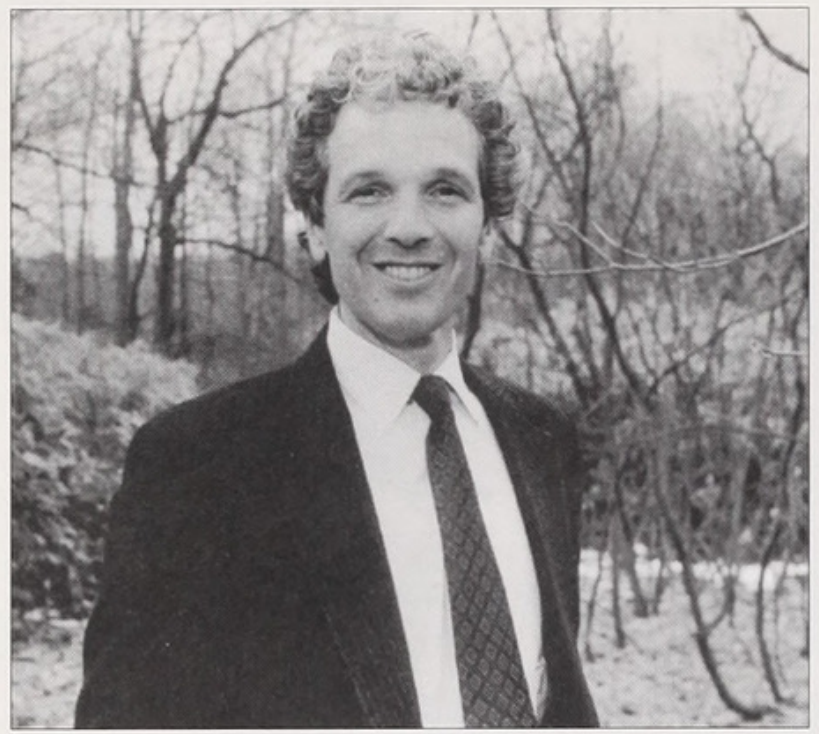

We regret to announce that after this issue a name will disappear from the roster of our Editorial Committee. Richard Schulhof, Director of Education and Public Programs since 1992, has left the Arboretum to undertake the directorship of Descanso Gardens, La Cañada Flintridge, in his native southern California. Descanso boasts the world's largest collection of camellias as well as an outstanding rose collection, but even more interesting botanically is its native vegetation. This includes an extensive area of chapparal and a pristine woodland of coastal live oak, Quercus agrifolia, one of the few that are publicly accessible in southern California. Descanso can be visited via the World Wide Web at http. //www.mobot.org/aabga/member.pages/descanso.html/.

Richard came to the Arboretum in 1989 as a Putnam Fellow and quickly took the role of coordinator of the master planning project. He was instrumental in interpreting both the cultural and scientific missions of the Arboretum, and to him goes credit for the National Endowment for the Humanities grants for the development of a permanent exhibit to be unveiled this autumn. Richard has been a much valued colleague; we wish him all the best.

\section{New Staff}

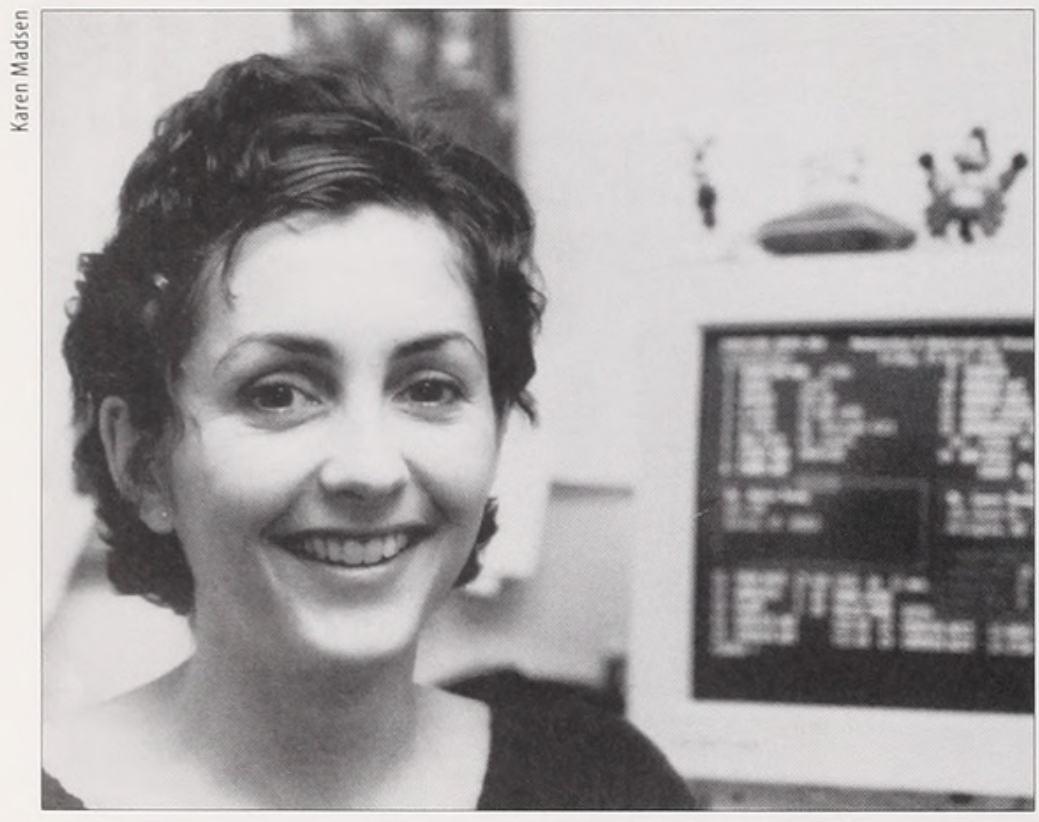

The Development Department at the Arboretum announces the addition of two new staff members. Kelly Harvey replaces David Sieks as the Membership Assistant. In this newly expanded role, Kelly manages all activities related to the Friends of the Arnold Arboretum, including new member acquisition, special membership events, and the membership database. She joins us from the Harvard Graduate School of Design, where as office manager she coordinated the school's computer helpdesk. She also brings prior experience in public relations and fundraising from previous work as circulation assistant of the Harvard University Gazette and as membership assistant for Harvard's Sports Alumni Friends groups.

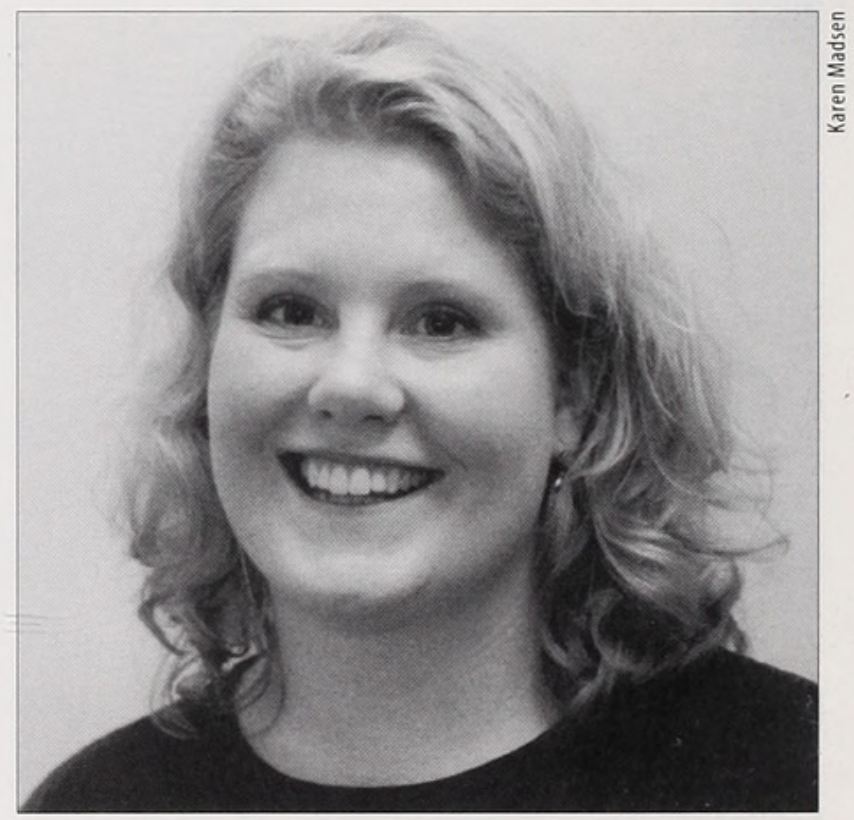

Kara Stepanian joins the Arboretum in the newly created position of Development Assistant. Kara's activities will focus on our fundraising initiatives including the live and silent auctions at the annual fall plant sale, creating and managing a development database, donor research, and special events. Kara comes to us from Harvard's Graduate School of Arts and Sciences Alumni Association where she worked with the alumni advisory council, planned events, and wrote for the alumni publication. Prior to that, she worked in development for the Seattle Symphony in Washington State. 


\section{PROG RAMS \&ै EVENTS}

The Arboretum's Education Department offers a wide variety of courses, programs, and lectures in horticulture, botany, and landscape design. A selection of summer courses is shown here. For a complete catalogue of programs and events at the Arboretum, call 617/524-1718 x 162. Please note that fees shown in boldface are for members of the Arboretum. For information about becoming a member, call 617/524-1718 x 165 .

HOR 338 Basic Care for Trees and Shrubs Joseph J. Camilliere III, Consulting Arborist

Trees and shrubs are key structural elements in the landscape. Learn the basic techniques used to care for and enhance woody ornamental trees and shrubs, from identifying stresses to pruning and feeding.

Session 1: Basic Anatomy and Physiology

Understanding tree growth and function

Session 2: Evaluating Trees and Shrubs

Recognizing the signs and symptoms of insects, diseases, and environmental stresses; applying basic treatment tactics

Session 3: Proper Care for Maximum Health Pruning, maintaining shrubs at desired sizes, fertilizing - what to use and when, mulching and root care, preventing mechanical injury, when to call a professional arborist

Fee: $\$ 45,54$

3 Mondays, July 8, 15, 22/ 6:30-8:30 pm (CE)

\section{HOR 393 Planning the Drought-Tolerant Garden}

\section{Gary Koller, Senior Horticulturist, Arnold Arboretum}

The drought of 1995 took its toll on the gardens of New England and left many gardeners wondering how to proceed. This class will focus on design concepts of xeriscaping, or planning the garden for greater drought tolerance and less dependence on supplemental irrigation. Participants will look at the concepts of water conservation in the garden, designs that group plants based on watering needs, and plant selections that are both drought tolerant and efficient in water usage. Sessions will include discussion, practical planting layouts, and plant lists, as well as a walk to look at drought-tolerant plants growing in the Arnold Arboretum collections.

Fee: $\$ 58, \$ 70$

3 Wednesdays, July 10, 17, 24/ 4:00-6:00 pm (DG)
BOT 119 The August Landscape: Trees, Shrubs, and Vines

Richard Stomberg, Manager, Harvard University Herbaria Glasshouses

The ornamental potential of plants in August can be overlooked when heat-dazzled Bostonians concentrate their attention on beaches and vacations. Sophora japonica, Evodia daniellii, and Clerodendrum trichotomum will be among the plants explored on this warm-weather walk through the Arboretum.

Fee: \$12, \$15

Saturday, August 17/ 10:00-noon (DG)

HOR 136 Ornamental Grasses

Darrell Probst, Horticultural Consultant and Landscape Designer

In the diverse world of ornamental grasses exist plants suitable for gardens of every size and for sunny, shady, wet, and dry locations. Some grasses are so large and dramatic that they can be used as shrubs or specimen plantings; others are miniatures, at home in the small-scale landscape. Their colors form a rainbow of greens, pinks, creams, blues, golds, and whites. This introduction to decorative grasses will focus on these versatile perennials.

Fee: $\$ 16, \$ 19$

Tuesday, August 20/ 6:30-8:30 pm (CE)

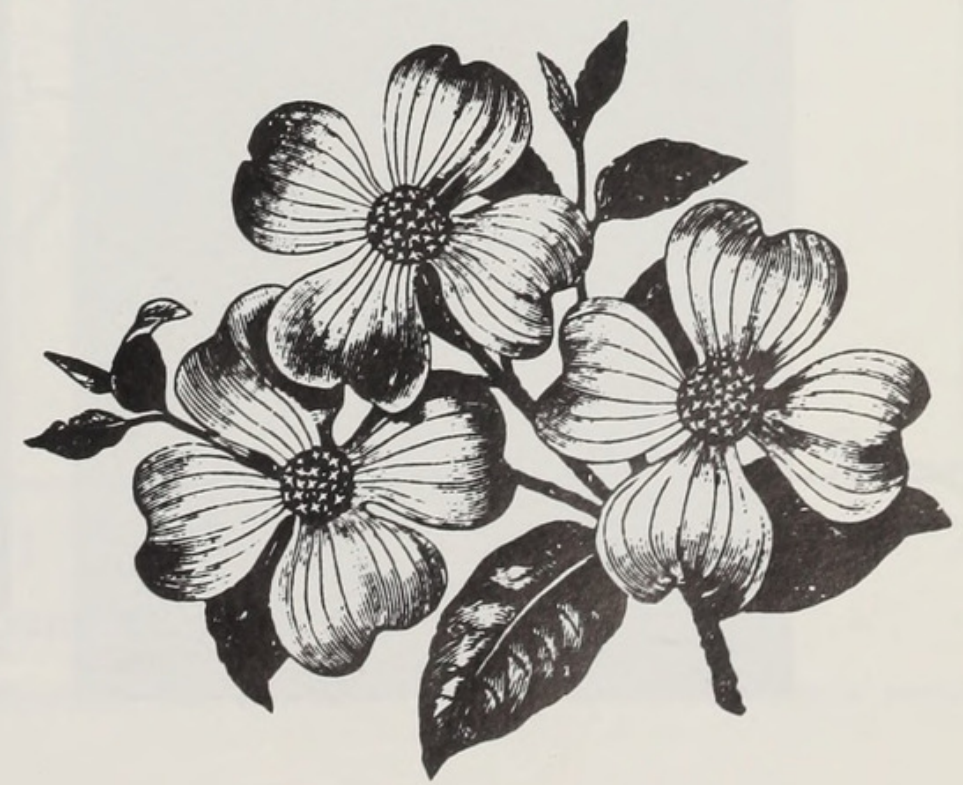




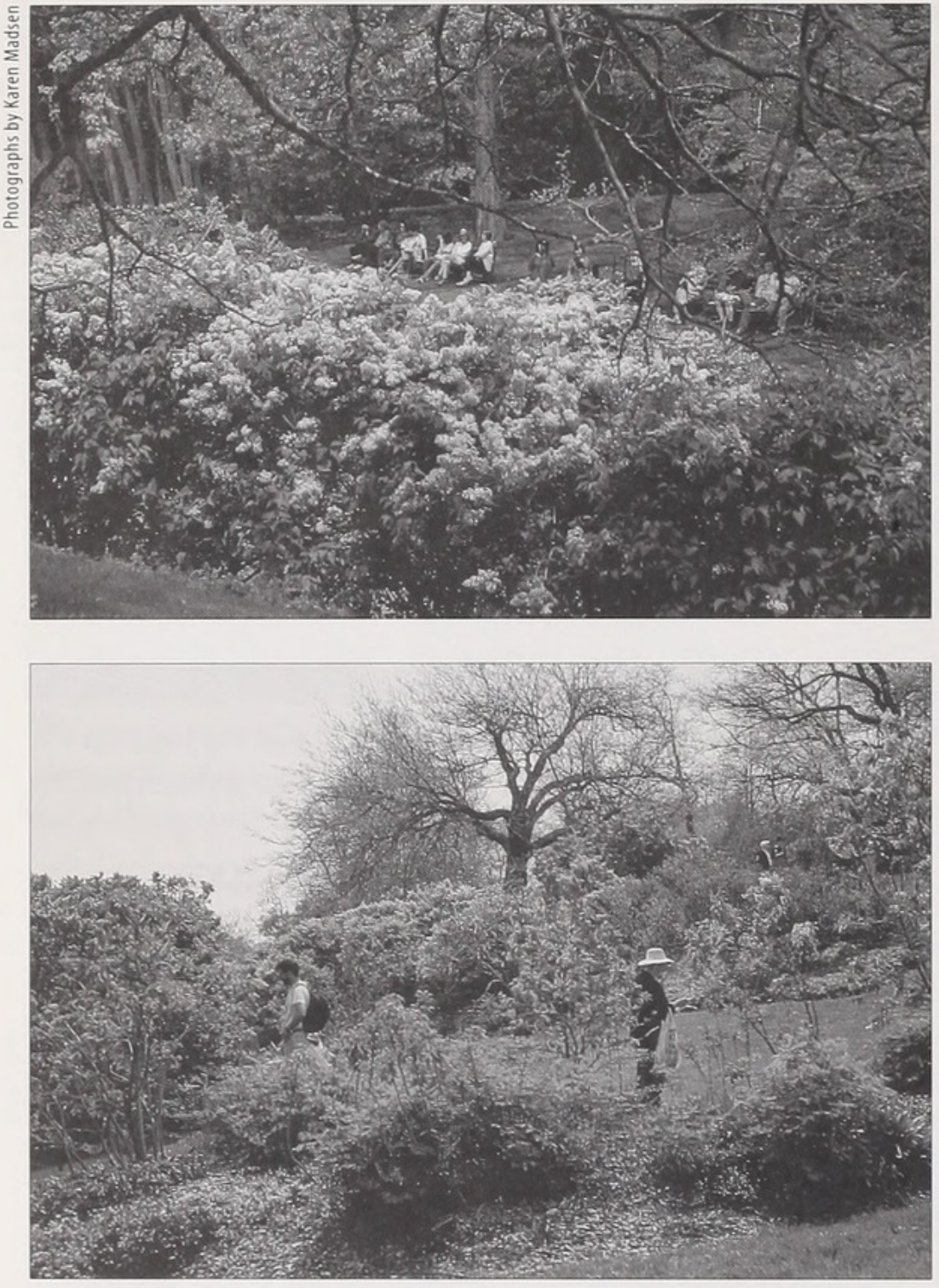

\section{Lilacs 1996 A Cause for Celebration}
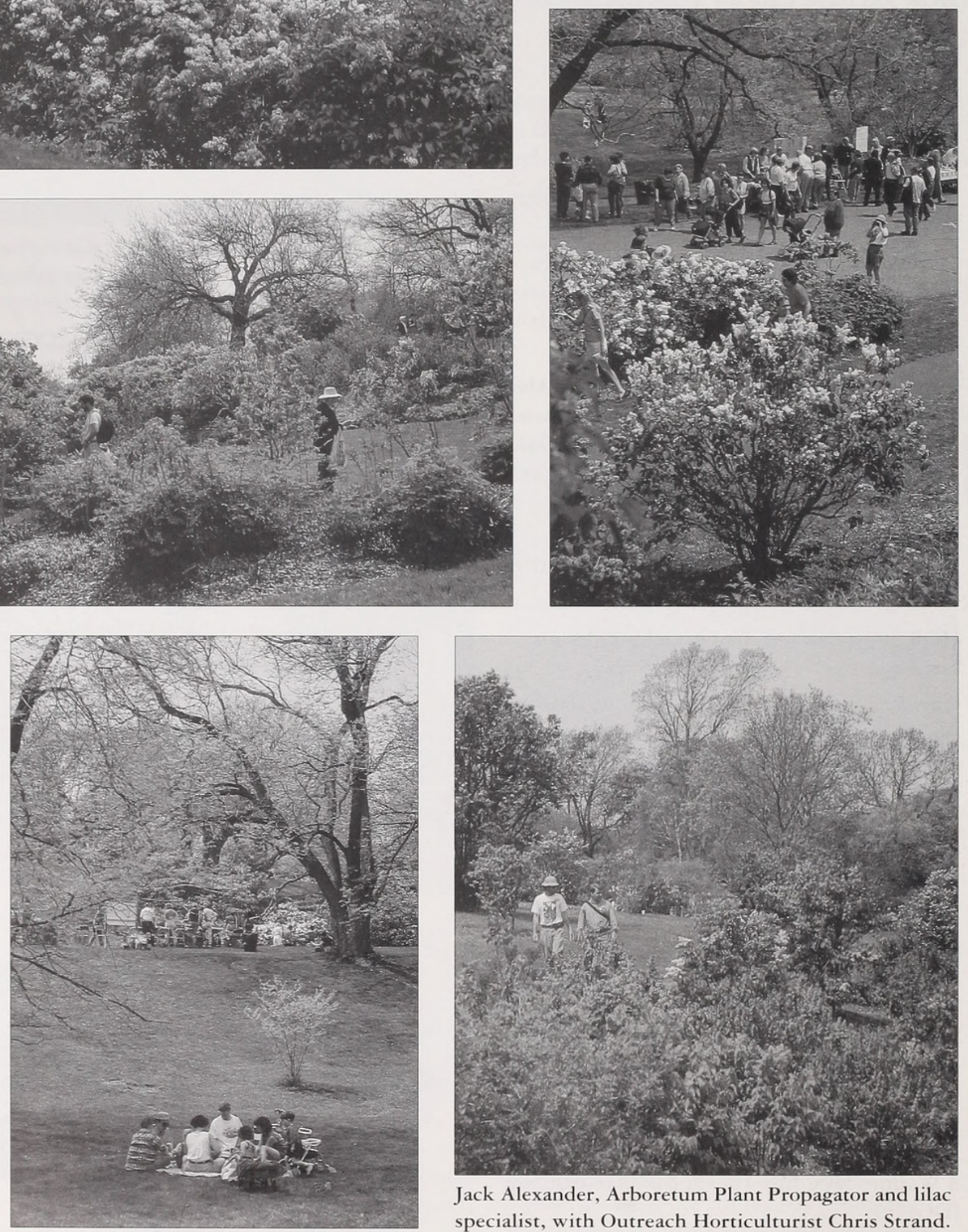

Jack Alexander, Arboretum Plant Propagator and lilac specialist, with Outreach Horticulturist Chris Strand. 
to correct the problem. In these cases, the advisability of removing girdling roots is uncertain even where the individual roots are distinct enough to make removal practicable: if a large root constricting the trunk is removed, a substantial portion of the root system may be lost with it. Root loss can also cause stress, decline, and even death of the tree.

After these disappointing initial excavations, the Mt. Prospect study focused on younger parkway trees that had been in place for only three to ten years. Trees of this age are well enough established so that the stress from root crown excavation is minimal, but young enough so that severe girdling has not yet developed. In this second phase of the study, a total of 120 root crowns were excavated over a two-year period. The number of girdling roots was recorded, and these girdling roots were removed when this could be done without substantially reducing the total root system. The approximate age of each root removed was determined by smoothing a cross section and counting the number of annual rings.

Tree roots can be classified as (1) primary roots, which radiate out from the base of the tree-like spokes of a wheel; (2) secondary roots, which are lateral branches of primary roots that grow almost perpendicular to them; and (3) tertiary roots, which are lateral branches of secondary roots. Almost all the girdling roots found were secondary or tertiary roots. This is not surprising since the nearly perpendicular branches of the spoke-like primary roots are more likely to wrap around the base of the trunk or cross other roots.

A strong relationship between transplanting and girdling root formation became apparent in

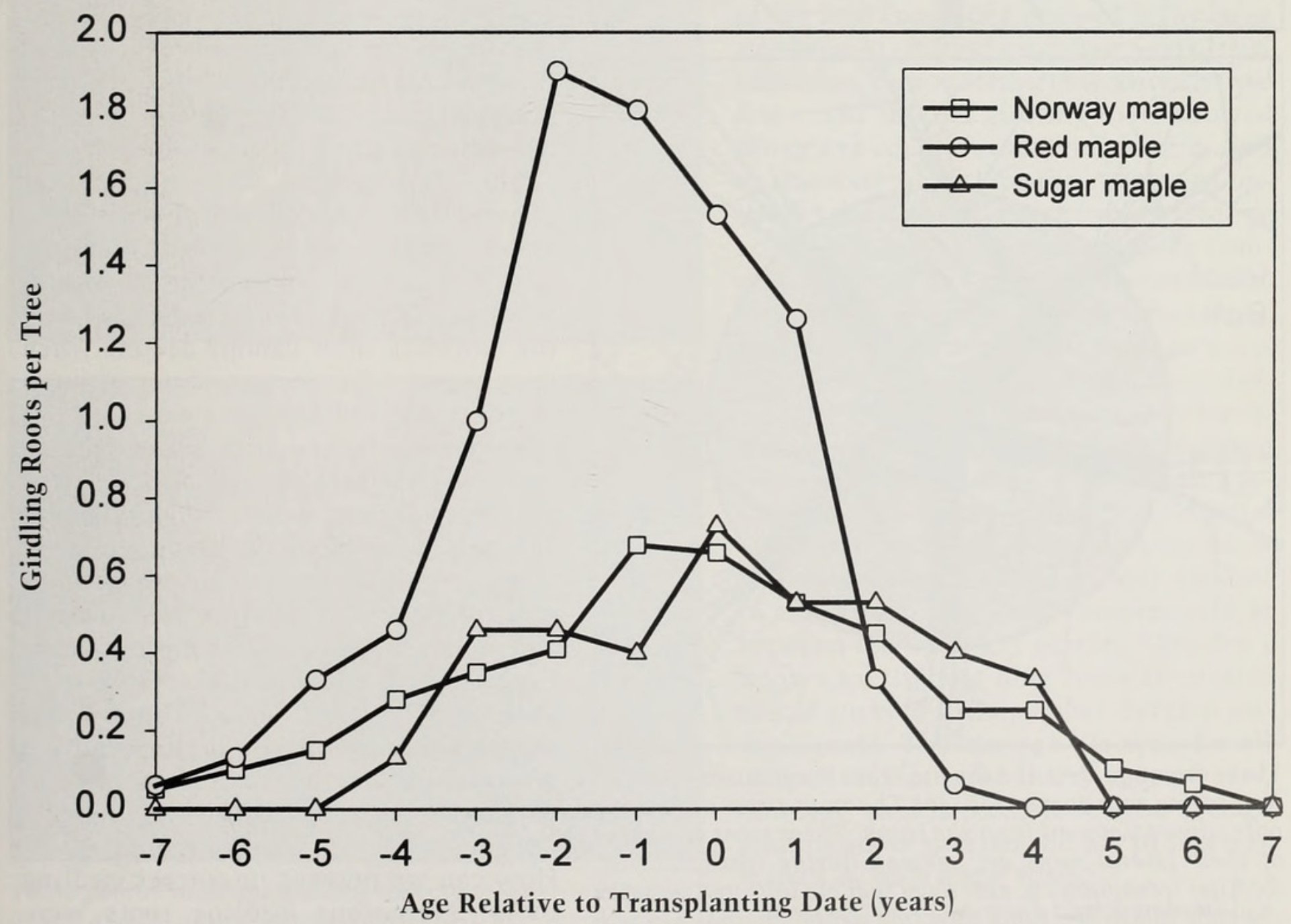

This chart relates the age of the girdling roots of Norway, red, and sugar maples to the number of years since transplantation. 

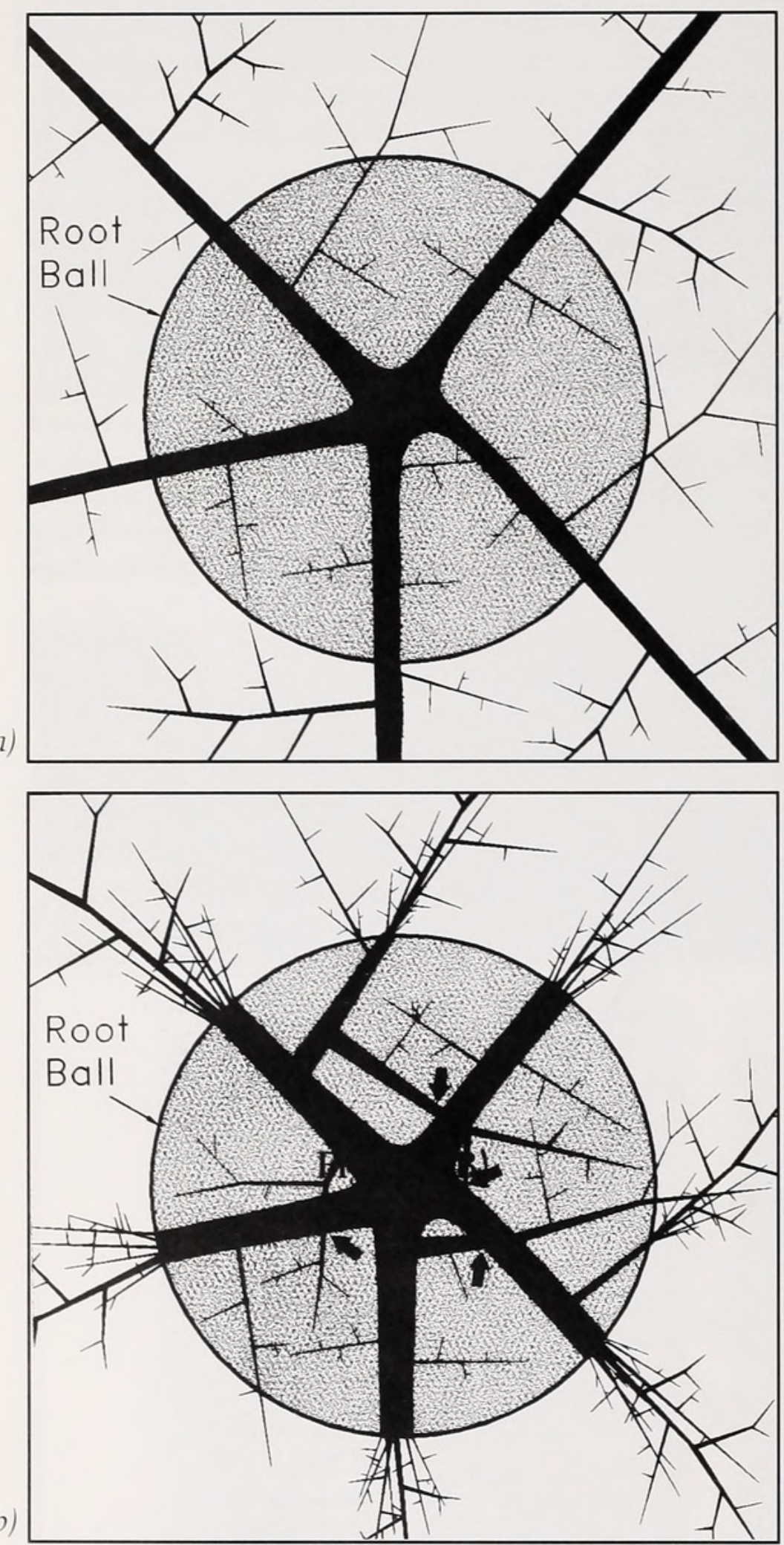

These drawings describe the probable mechanism involved in girdling root formation: (a) The major roots of a tree normally radiate out from the trunk. These roots and some of their lateral roots are severed during transplanting. (b) After transplanting, new roots that are initiated from the cut ends follow the same direction as the original. Growth in existing and new lateral roots is stimulated and these can become girdling roots, as indicated by the arrows. all three maple species, with the majority of the girdling roots being initiated within one year of transplanting. This fact, together with the finding that most girdling roots are secondary or tertiary roots, enabled us to construct a hypothesis of the way girdling roots may be formed on fieldgrown transplanted trees. Normally, secondary roots grow slowly and remain quite small as long as the primary root is intact. When the tree is dug in the nursery and the large radiating primary roots are severed, however, the secondary roots often begin to grow more rapidly. In addition, new secondary roots may form some distance behind the cut end of the primary root. All these vigorously growing secondary roots are located close to the base of the trunk and are well positioned to become girdling roots as both the roots and the trunk grow larger. If severing the primary roots during transplanting is indeed the stimulus for girdling root formation, it is easy to understand why girdling roots do not generally occur in forests.

The Mt. Prospect study found that young Norway maples and sugar maples had an average of four girdling roots per tree. Red maples had even more-nearly twice as many. Why is it, then, that only the Norways show canopy decline when they mature? Excavation of root crowns of sugar and red maples twenty-one to twenty-eight years after transplanting revealed very few girdling roots. Those that were present were relatively small, and all were less than twelve years old. By contrast, girdling roots of Norway maples of similar age were much more numerous and ranged in age up to twenty-four years. For unknown reasons, it seems that the girdling roots that develop on red and sugar maples as a result of transplanting are short-lived, unlike the case of Norway maples.

How can we prevent or correct girdling roots? Numerous girdling roots were removed during the first phase of the Mt. Prospect study in hopes of preventing 
(a)

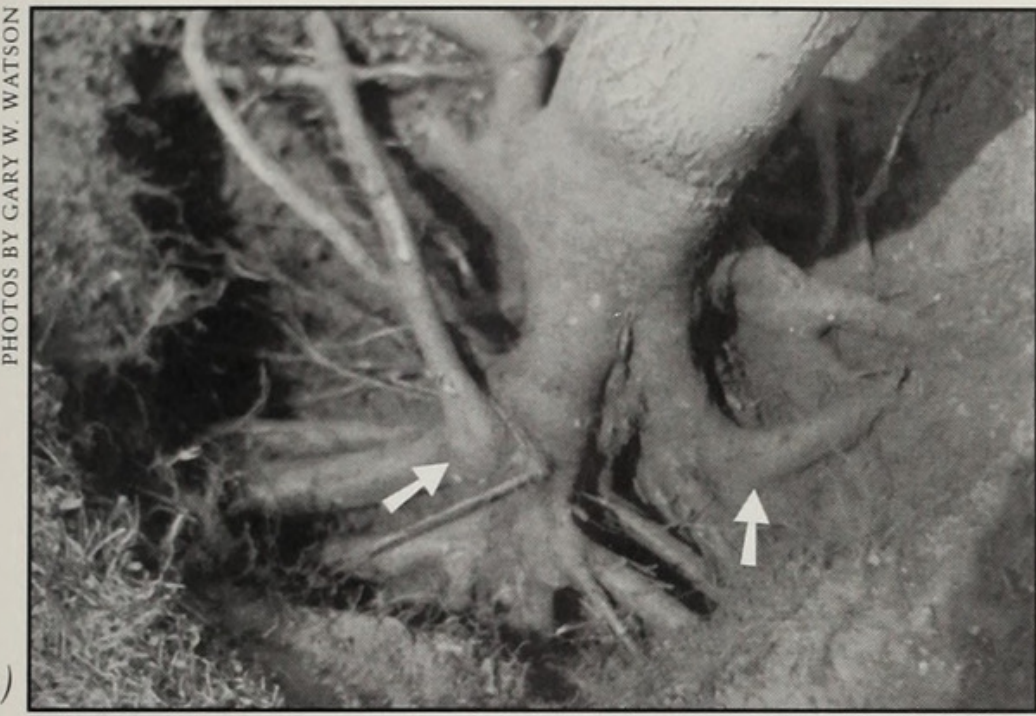

(b)

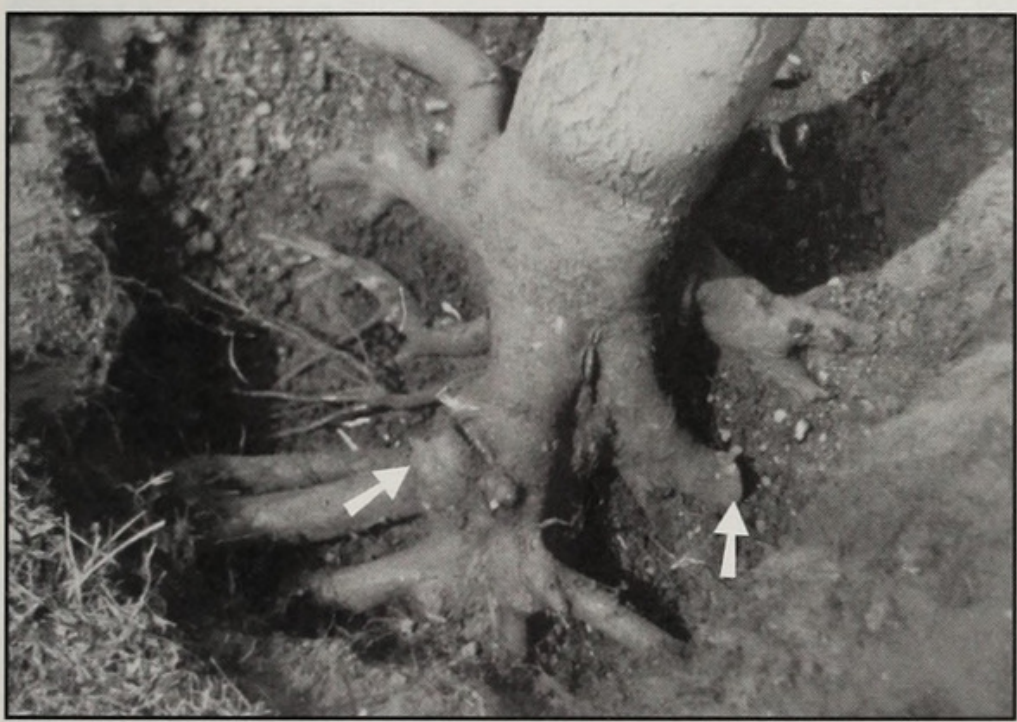

(c)

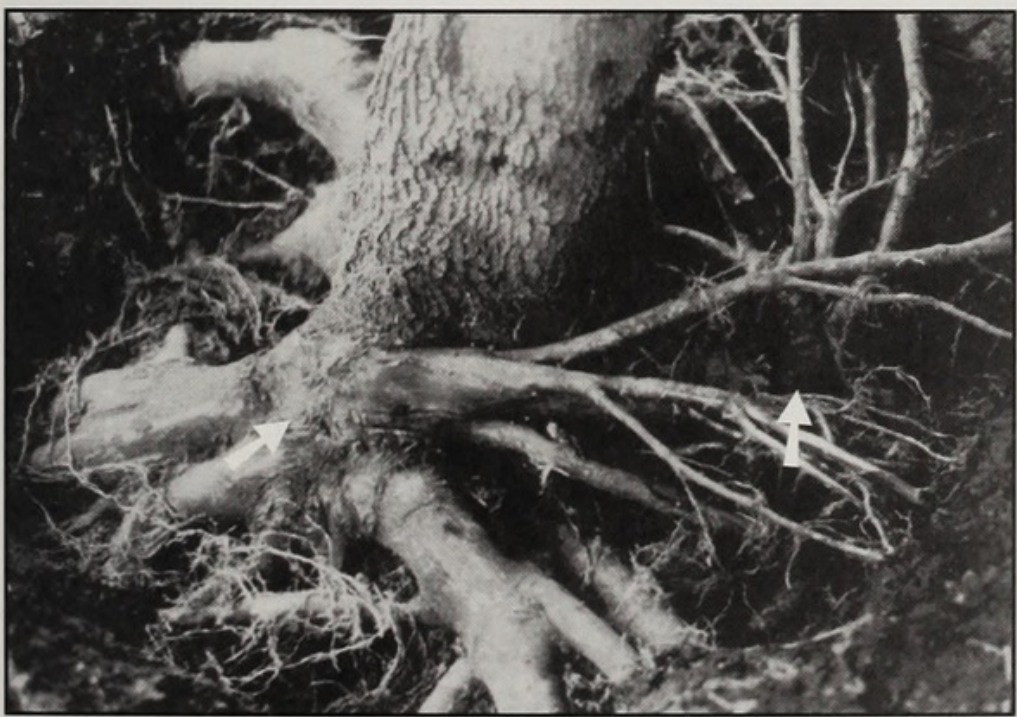

These photos show the girdling roots of a Norway maple (a) before and (b) after corrective treatment, and then again (c) four years later. The arrows indicate the same location in all photos. canopy decline in the future; the process of excavation and root removal is time consuming but would be worth the effort if it were effective. To determine whether this was the case, one quarter of the same Norway maple trees were excavated again in 1992 and their roots compared to photos taken at the time of the 1987 excavation. It soon became clear that one or more roots had consistently regenerated from each root removal site. The new roots, just like the old ones, were usually nearly perpendicular to the radially oriented primary roots and well positioned to become girdling roots.

This finding was discouraging, but there may still be hope. It was encouraging to learn that the root systems of Norway maples have diverse growth habits. Those with many large girdling roots at the time of the first excavation showed many large regenerated girdling roots four years later. Likewise, root systems that initially had fewer and smaller girdling roots showed fewer and smaller regenerated roots. And of the sixty older Norway maples examined in the first phase of the study, girdling and potentially girdling roots were completely absent on two trees. Theoretically, this genetic diversity may allow root stock to be selected and propagated so as to reduce or eliminate girdling roots altogether.

Until better root stocks are developed, communities should avoid overplanting Norway maples (or any other single species) and be prepared to accept substantial losses from girdling roots as the trees reach maturity. What these losses may amount to can be estimated only imprecisely at between ten and forty percent. ${ }^{4}$ We don't know exactly how long Norway maples would survive if they didn't develop girdling roots. The average life span for all urban trees is only thirty-seven years, however, so it is possible that on average girdling roots shorten the life of Norway maples by only a few years.

It would be easy to say that we shouldn't plant Norway maples because of the girdling root problem, but then we might also 

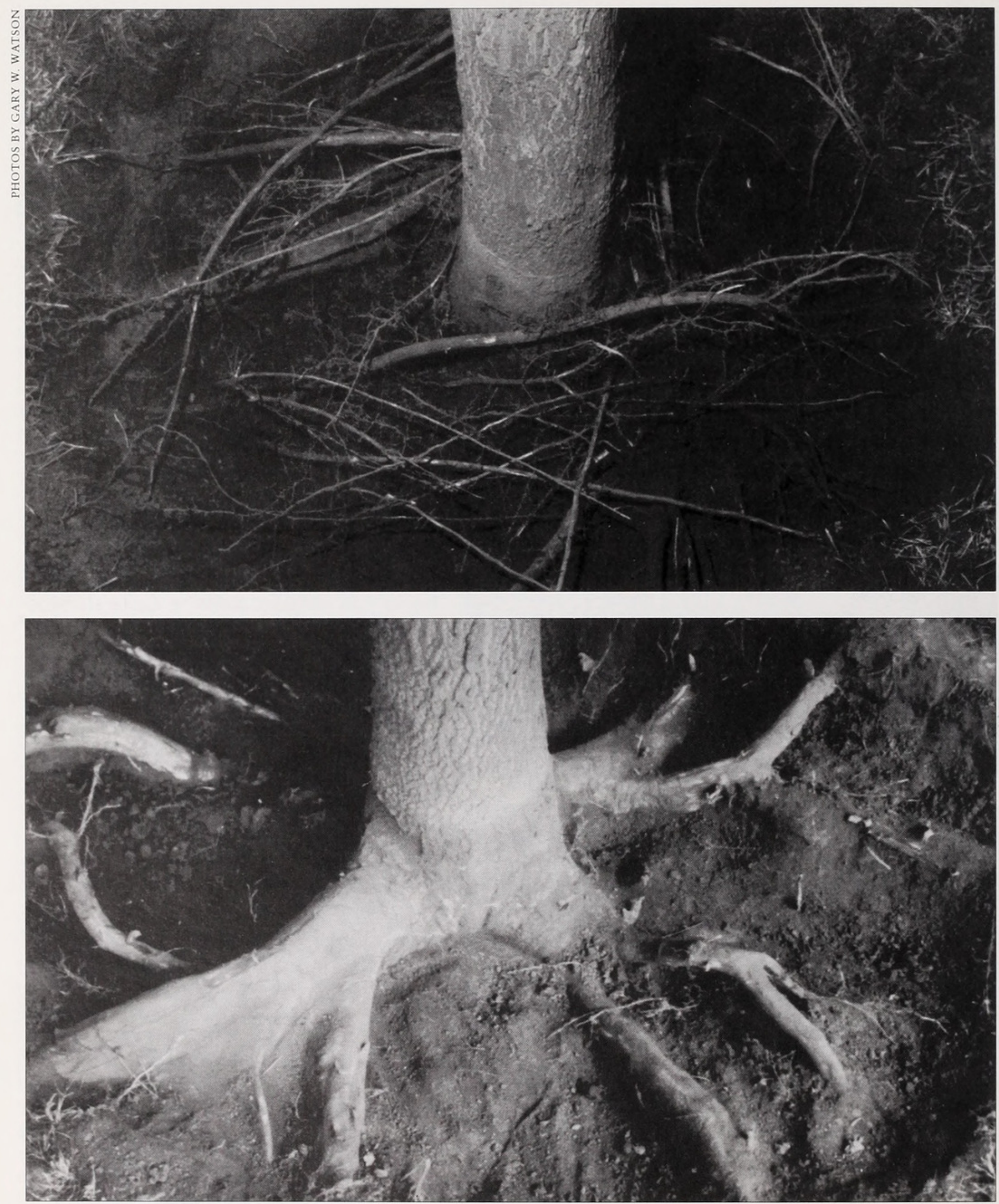

These photos show examples of the diverse character of Norway maple root development. Selection of root stock like that seen on the right in the lower photo may be the best way to eliminate most girdling root problems in the future. 
have to stop planting redbuds (Cercis canadensis) because they can get verticillium wilt, green ashes (Fraxinus pennsylvanica) because they can get borers, and red oaks (Quercus rubrum) because they are susceptible to oak wilt. There is an appropriate place for every tree. For reasons of historical significance, American elms are still planted on the National Mall in Washington, DC, even though they may eventually die from Dutch elm disease, and in fact, they may survive the harsh site conditions as well as or better than any other tree. You might not want to plant a Norway maple in a location where survival for many decades is important, but if a life span of thirty years is acceptable, there is no reason not to plant one. The Village of Mt. Prospect continues to plant Norway maples, but tries to use them in mixed species plantings so that no single problem can wipe out all the trees in an area.

Gary Watson is Root System Biologist at The Morton Arboretum in Lisle, Illinois. Sandra Clark is Superintendent of Forestry, Village of Mt. Prospect, Illinois.

\section{Frequency of girdling roots in relation to planting depth for all maple species}

It is often contended that trees planted too deeply have more girdling roots, but the matter has never been formally studied. The Mt. Prospect study found no relationship between planting depth and girdling roots. However, the data do show how often trees are planted too deeply in the landscape. Over half the trees studied had been planted two to eight inches too deep, even though all were planted by reputable commercial landscape companies. Planting too deep is one of the major causes of death of trees of all species planted in the landscape. No soil should cover the top of the root ball when the planting job is complete.

$\begin{array}{ccc}\begin{array}{c}\text { Root flare relative } \\ \text { to grade [inches }(\mathrm{cm})]^{*}\end{array} & \begin{array}{c}\text { Number of } \\ \text { trees }\end{array} & \begin{array}{c}\text { Average number of } \\ \text { girdling roots/tree }\end{array} \\ +1(2.5) & 1 & 4 \\ \text { at grade } & 21 & 5 \\ -1(2.5) & 2 & 3 \\ -2(5.0) & 13 & 5 \\ -3(7.5) & 2 & 9 \\ -4(10.0) & 7 & 5 \\ -5(12.5) & 1 & 4 \\ -6(15.0) & 4 & 5 \\ -7(17.5) & 1 & 1 \\ -8(20.0) & 2 & 2\end{array}$

\section{Endnotes}

${ }^{1}$ Robert L. Tate, Bole characteristics associated with girdled Norway maple trees, Journal of Arboriculture (1981) 7(10): 308.

${ }^{2}$ A Technical Glossary of Horticultural and Landscape Terminology. Washington, DC: Horticultural Research Institute, 1971.

3 Three other species, green ash (Fraxinus pennsylvanica), honeylocust (Gleditsia triacanthos), and littleleaf linden (Tilia cordata) were also studied but were found to have less than half as many girdling roots as any of the maples. Girdling roots were especially infrequent in lindens. The authors' documentation of these findings can be found in Journal of Arboriculture 16(8): 197-202 and 19(5): 278-280.

4 These percentages are based on R. L. Tate's number of girdling roots and percent of encirclement as well as on data and experience from our own work.

5 This figure for average life span is taken from B. Skiera and G. Moll, Trees in the Red, Urban Forests 12(1): 9-11. 


\section{$2 \mathrm{BHL}$ Biodiversity Heritage Library}

Watson, Gary W. and Clark, Sandra. 1996. "When the Roots Go Round and Round." Arnoldia 56(1), 15-21.

View This Item Online: https://www.biodiversitylibrary.org/item/216957

Permalink: https://www.biodiversitylibrary.org/partpdf/251112

\section{Holding Institution}

Harvard University Botany Libraries

\section{Sponsored by}

BHL-SIL-FEDLINK

\section{Copyright \& Reuse}

Copyright Status: In copyright. Digitized with the permission of the rights holder.

Rights Holder: Arnold Arboretum of Harvard University

License: http://creativecommons.org/licenses/by-nc-sa/4.0/

Rights: https://biodiversitylibrary.org/permissions

This document was created from content at the Biodiversity Heritage Library, the world's largest open access digital library for biodiversity literature and archives. Visit BHL at https://www.biodiversitylibrary.org. 